\section{Atrkivoc $\checkmark$}

Archive for

Organic Chemistry
The Free Internet Journal

for Organic Chemistry
Paper

Arkivoc 2017, part iv, 1-11

\title{
Synthesis and in vitro antiproliferative effect of isomeric analogs of cyclobrassinin phytoalexin possessing the 1,3-thiazino[5,6-b]indole-4-one skeleton
}

\author{
Péter Csomós, ${ }^{\mathrm{a}, \mathrm{b}}$ Lajos Fodor, ${ }^{* a, b}$ István Zupkó, ${ }^{\mathrm{c}}$ Antal Csámpai, ${ }^{\mathrm{d}}$ and Pál Sohár*d
}

${ }^{a}$ Central Laboratory, County Hospital, H-5701, Gyula, POB 46, Hungary

${ }^{b}$ Institute of Pharmaceutical Chemistry, University of Szeged, and Research Group of Stereochemistry of the Hungarian Academy of Sciences, H-6720, Szeged, Eötvös u. 6., Hungary 'Department of Pharmacodynamics

and Biopharmacy, University of Szeged, H-6701, POB 427, Hungary

${ }^{d}$ Institute of Chemistry, Eötvös Loránd University, H-1518 Budapest, POB 32, Hungary

E-mail: fodor@pandy.hu, sohar@chem.elte.hu

Received 11-25-2016

Accepted 03-03-2017

Published on line 04-18-2017

\section{Abstract}

Isomeric analogs of cyclobrassinin phytoalexin possessing the 1,3-thiazino[5,6-b]indole-4-one skeleton have been prepared. Starting from $1 \mathrm{H}$-indole-2-carbonyl isothiocyanate, $\mathrm{N}$-aryl- $\mathrm{N}^{\prime}$-(indole-2-carbonyl)-substituted thiourea or the corresponding $\mathrm{S}$-aryl- $\mathrm{N}$-(indole-2-carbonyl)dithiocarbamate intermediates were prepared and then transformed by ringclosure via Hugerschoff reaction with phenyltrimethylammonium tribromide. Attempted synthesis of $N^{\prime}$-(indole-2carbonyl)- $N$-(3,4,5-trimethoxyphenyl)thiourea unexpectedly delivered the 2-(indole-2-carbonylamino)-5,6,7-trimethoxybenzothiazole ring system. The structures of the new ring systems were determined by means of IR and NMR spectroscopy. The new derivatives synthesized exert moderate in vitro antiproliferative effects on a panel of adherent human cell lines (HeLa, A2780, A431 and MCF7).

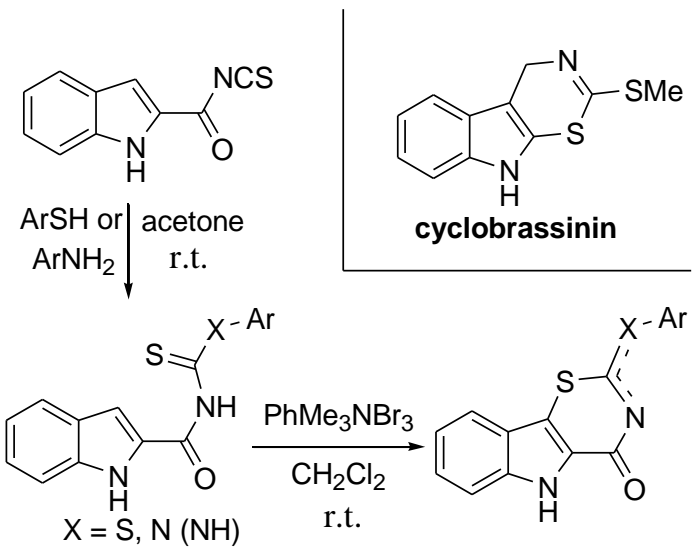

Keywords: 1,3-Thiazino[5,6-b]indole-4-ones, indole-2-carboxamide moiety, phytoalexin isomeric analogs, IR, ${ }^{1} \mathrm{H}$ and ${ }^{13} \mathrm{C}$ NMR 


\section{Introduction}

Among the possible isomers of 1,3-thiazinoindoles condensed at bond $b$ of the indole skeleton, the most interesting derivatives are 1,3-thiazino[6,5-b]indoles. Compounds possessing this ring system, such as cyclobrassinin and their biosynthetic or synthetic precursors (brassinin), belong to the family of natural phytoalexins and were isolated from cruciferous plants, first from Chinese cabbage (Figure 1). ${ }^{1}$

Phytoalexins are antimicrobial substances of low molecular weight produced by plants in response to infection or stress, which form part of their active defense mechanisms, probably as a result of the de novo synthesis of enzymes, as a part of the immune system of plants. ${ }^{2}$ In addition to their antimicrobial activities, brassinin and cyclobrassinin have various other pharmacological effects. They inhibit the formation of preneoplastic mammary lesions in culture. ${ }^{3}$ They also exerts in vitro antiproliferative effect on a number of different human cell lines. ${ }^{4,5}$ As for the pharmacodynamic mechanism, brassinin and its derivatives are inhibitors of indolamine 2,3-dioxygenase, a new cancer immunosuppression target. ${ }^{6}$ Izutani et al. revealed, that brassinin induces G1 phase arrest through increase of p21 and p27 by inhibition of the phosphatidylinositol 3-kinase signalling pathway in human colon cancer cells. ${ }^{7}$ Kello et al. investegated ROSdependent antiproliferative effect of homobrassinin, a brassinin derivative, in human colorectal cancer caco2 cells. ${ }^{8}$ Lee et al. showed that brassinin inhibits STAT3 signaling pathway through modulation of PIAS-3 and SOCS-3 expression and sensitizes human lung cancer xenograft in nude mice to paclitaxel. ${ }^{9}$
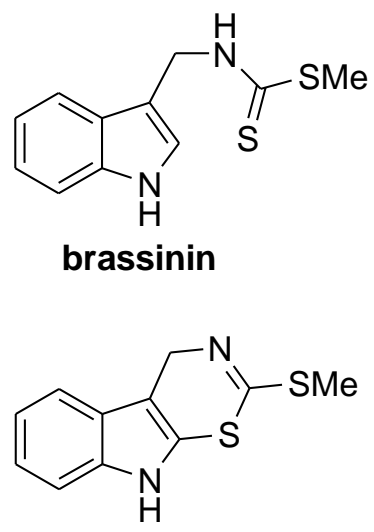

cyclobrassinin

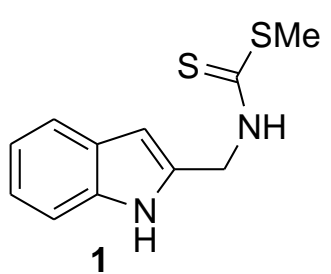

1

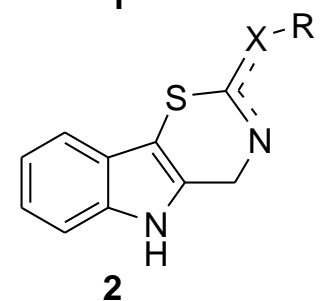

2

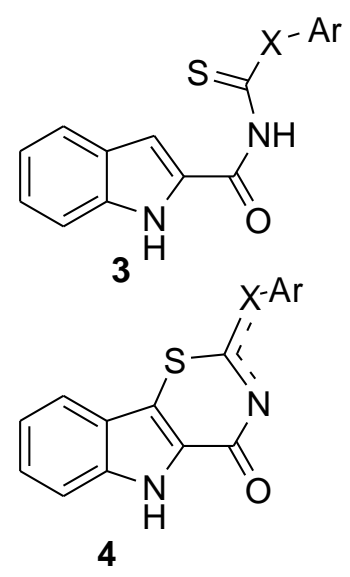

4

$$
\mathrm{X}=\mathrm{S}, \mathrm{N}(\mathrm{NH}) ; \mathrm{R}=\mathrm{Me}, \mathrm{Bn}, \mathrm{Ar}
$$

\section{Figure 1}

Extensive investigations have been focused on the natural members of $S, N$-phytoalexins from antiproliferative point of view. In contrast, relatively few isomeric bioisoster indole compounds of this type were sythesized and investigated from pharmacological aspects. A series of 2-alkyl- or 2-arylimino-1,3thiazino[5,4- $b]$ indol-4-one derivatives ${ }^{10}$ inhibits human leukocyte elastase and $\alpha$-chymotrypsin. The 4-oxo-1,3thiazino[6,5-b]indole derivatives of cyclobrassinone were prepared Kutschy et al. It turned out later, however, that the original structure of this phytoalexin was most probably misinterpreted. ${ }^{11}$

In our previous work we prepared isobrassinin (1), 2-methylthio-1,3-thiazino[5,6-b]indole (isocyclobrassinin, 2, X = S, R = Me, Figure 1) and its 2-benzylthio- analog $2(X=S, R=B n$, Figure 1 ) and found them to exert good in vitro antiproliferative effects on cervical adenocarcinoma (HeLa), breast adenocarcinoma (MCF7) and squamous skin carcinoma (A431) cell lines. ${ }^{5}$ For the investigation of structure- 
activity relationships, further 2-aryl-1,3-thiazino[5,6-b]indole analogs were synthesized. The highest cytotoxic effect was displayed by 2-phenylimino-1,3-thiazino[5,6-b]indole $2(X=N, R=P h$, Figure 1), which demonstrated inhibitory activity on the above three cell lines comparable to that of cisplatin. ${ }^{5}$

In order to improve the possible efficacy our attention next turned to the incorporation of indol-2carboxamide moiety (3, 4; Figure 1) into isobrassinin and isocyclobrassinin analogon compounds (1, 2; Figure 1). Motifs containing the indole-2-carboxamide moiety have the increased ability to bind to different receptors and enzymes. Compounds containing this pharmacophore, therefore, can be found in varied biologically active compounds. Certain derivatives, which target allosteric modulation of cannabnoid receptor 1 (CB1), ${ }^{12}$ glycogene phosphorylase inhibitors, ${ }^{13}$ neurotensin (NT) (8-13) mimetics, ${ }^{14}$ monoamine oxidase inhibitors, ${ }^{15}$ agonists of nociceptin/orphanin FQ (N/OFQ receptors, ${ }^{16}$ dopa $D_{3}$ receptor, ${ }^{17}$ selective antagonists of NR2B subunit containing $N$-methyl- $D$-aspartate (NMDA) receptor, ${ }^{18}$ can be useful in different mental and CNS disorders. Furthermore, other indole-2-carboxamide counterparts may act as antioxidants, ${ }^{19}$ coagulation factor $\mathrm{Xa}$ inhibitors ${ }^{20}$ and can have useful in different pathological conditions, such as heart failure conditions, ${ }^{21}$ diabetes, ${ }^{22}$ osteoporosis, ${ }^{23}$ Chron's dishease, ${ }^{24}$ and certain infections. ${ }^{25}$ These are also inhibitors of different enzymes (Rho kinase, ${ }^{26}$ endothelin-converting enzyme, ${ }^{27}$ vascular endothelial growth factor FR2 VEGFR2 tyrosine kinase, ${ }^{28}$ topoisomerase I, $^{29}$ type $517 \beta$-hydroxysteroid dehydrogenase, ${ }^{30}$ tubulin polimerization ${ }^{31}$ ), may act as apoptosis inducers ${ }^{32}$ and potential DNA-intercalating compounds ${ }^{33}$ (like duocarmycin A). In addition, they exert promising and remarkable in vitro antiproliferative effects.

Subsequent to our recent investigations on 1,3-thiazinoindole derivatives ${ }^{5,34-36}$ and the chemistry of sulfurand nitrogen-containing heterocycles with condensed skeleton, ${ }^{37}$ we set out to investigate the synthesis, structure and in vitro antiproliferative effect of new 1,3-thiazino[5,6-b]indole-4-one derivatives and their intermediates.

\section{Results and Discussion}

Our starting material $1 \mathrm{H}$-indole-2-carbonyl isothiocyanate 7 was obtained from $1 \mathrm{H}$-indole-2-carboxylic acid (5)

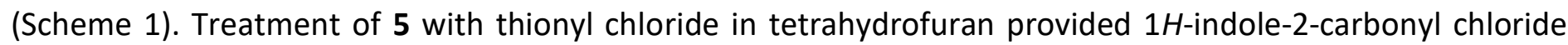
(6), which was reacted with potassium thiocyanate in acetone at room temperature. The reaction furnished isothiocyanate 7, which was used in the next step without any further purification (Scheme 1).

The key intermediate $N, N^{\prime}$-disubstituted thioureas $9 a-c$ were synthesized form acyl isothiocyanate 7 by its reaction with substituted aniline derivatives $\mathbf{8 a - c}$ in acetone in good yields (Scheme 1). According to our previous results for the preparation of our target 1,3-thiazino[5,6-b]indole-4-one derivatives, the Hugerschoff reaction was applied. The oxidative cyclization of (4-chlorophenyl)thiourea derivative 9a with phenyltrimethylammonium tribromide in dichloromethane yielded thiazinoindole 10. It turned out, however, that this compound exists as an equilibrium mixture of tautomers 10-endo and 10-exo in hexadeuterodimethyl sulfoxide under NMR measuring conditions.

4-(Ethoxycarbonyl)phenyl-substituted thiourea $\mathbf{9 b}$ gave the excepted 2-[4-(ethoxycarbonyl)phenylimino]1,3-thiazino[5,6-b]indole-4-one (11) in good yield upon treatment with the bromide reagent applied above. For 3,4,5-trimethoxyphenyl-substituted 9c, the preferable reaction path in the Hugerschoff reaction was the formation of thiazole ring system 2-(indol-2-carbonylamino)-5,6,7-trimethoxy-benzothiazole (12). 
<smiles>O=C(O)c1cc2ccccc2[nH]1</smiles>

5<smiles></smiles>

10-exo<smiles>CCc1ccc(C)cc1</smiles>

10-endo<smiles>O=C(Cl)c1cc2ccccc2[nH]1</smiles>
$\underset{\text { acetone }}{\stackrel{\mathrm{KSCN}}{\longrightarrow}}$<smiles>Cc1cc2ccccc2[nH]1</smiles>

7 $10 \mathrm{~min}$<smiles>[R]c1cc(N)cc(C)c1[R]</smiles><smiles>[R]c1cc(NC(=S)NC(=O)c2cc3ccccc3[nH]2)cc([R])c1[R]</smiles>

8a-c $R$

a: $R=H, R^{1}=\mathrm{Cl}, \mathrm{R}^{2}=\mathrm{H} ; \mathbf{b}: \mathrm{R}=\mathrm{H}, \mathrm{R}^{1}=\mathrm{COOEt}, \mathrm{R}^{2}=\mathrm{H} ; \mathbf{c}: \mathrm{R}=\mathrm{R}^{1}=\mathrm{R}^{2}=\mathrm{OMe}$

\section{Scheme 1}

In order to obtain further analogs, 2-(4-chlorophenylthio)-1,3-thiazino[5,6- $b$ ]indole-4-one 15 was also prepared (Scheme 2). The reaction of isocyanate 7 with 4-chlorothiophenol provided dithiocarbamate derivative 14, which underwent oxidative ring closure reaction providing thiazine 15 when treated with phenyltrimethylammonium tribromide.

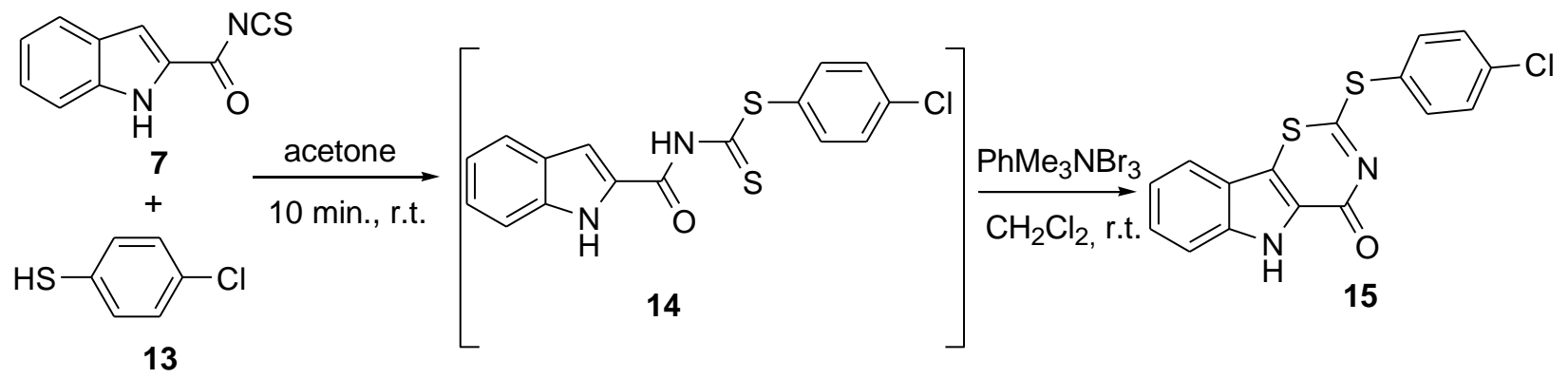

\section{Scheme 2}

The structures of the synthesized compounds were verified by $I R,{ }^{1} \mathrm{H}$ and ${ }^{13} \mathrm{C} N M R$ spectroscopy including 2D-HMQC, DEPT, ${ }^{1} \mathrm{H},{ }^{13} \mathrm{C}$ and ${ }^{13} \mathrm{C},{ }^{15} \mathrm{~N}-\mathrm{HMBC}$ measurments. Spectral data are given in Tables 1 and 2. 
These techniques provided unambiguous proof of the formation of the expected structures. The only exception is compound 12, which formed instead of desired 2-(3,4,5-trimethoxyphenylimino)-1,3-thiazino[5,6$b]$ indole-4-one. The benzthiazole moiety in $\mathbf{1 2}$ is verified by the following spectral data.

$>$ The benzene ring bearing the three methoxy substituents is penta-substituted (only a single aromatic carbon is protonated).

$>$ The six benzene carbons have carbon lines with different chemical shifts.

$>$ The substitution is asymmetric and the three methoxy groups have different ${ }^{1} \mathrm{H}$ and ${ }^{13} \mathrm{C}$ NMR signals.

$>$ The C-2 atom in the indole moiety is unsubstituted (the appropriate ${ }^{1} \mathrm{H}$ NMR singlet appears at 7.74 ppm).

$>$ The ring-chain tautomerism and the $\mathrm{N}$-inversion around the exo $s p^{2} \mathrm{~N}$ atom result in slow motion of the electron distribution in molecules $\mathbf{1 0}$ and $\mathbf{1 1}$. Consequently, the carbon lines of $\mathrm{S}-\mathrm{C}=$ and lactam $\mathrm{C}=\mathrm{O}$ groups have broadened and thus in the ${ }^{13} \mathrm{C}$ NMR spectrum cannot be assigned in every cases. Similarly, the $\mathrm{H}-2^{\prime}, 6^{\prime}$ signals in the ${ }^{1} \mathrm{H}$ NMR are broadened. Such broadenings are not observed in the spectra of 12.

It is to be noted that in compounds $9 \mathrm{a}-\mathrm{c}$ a chelate-type hydrogen bonding can form within the CO-NH-CS moiety. (A six-membered ring is formed by $\mathrm{H}$-bonding between the carbonyl oxygen and the SH-hydrogen of the $\mathrm{CO}-\mathrm{N}=\mathrm{C}-\mathrm{SH}$ tautomeric form). This assumption is supported by the following observations.

$>$ The VNH IR band of this group is extremely broadened (around $2000 \mathrm{~cm}^{-1}$ ) and thus hardly observable. Such a diffuse absorption band is characteristic of chelates. ${ }^{38}$

> The $\mathrm{C}=\mathrm{S}$ line in ${ }^{13} \mathrm{C}$ NMR appears at 179.5-179.7 ppm for 9a-c, outside the usual interval (173-176 $\left.\mathrm{ppm}^{39}\right)$.

> The electron-withdrawing or electron-releasing character of the substituents in the $\mathrm{NH}$-aryl group does not have any influence on the IR frequencies and the NMR shifts of the CO-NH-CS group. This makes highly probable that these two parts of the molecule (NHAr and CONHCS) are isolated from one another. All these features are in good agreement with the presence of the stable chelate ring.

Table 1. Characteristic IR frequencies ${ }^{\mathrm{a}}$ and ${ }^{1} \mathrm{H}$ NMR data ${ }^{\mathrm{b}}$ of compounds $\mathbf{9 a}-\mathrm{c}, \mathbf{1 0}-\mathbf{1 2}$ and $\mathbf{1 5}^{\mathrm{c}}$

\begin{tabular}{|c|c|c|c|c|c|c|c|c|c|c|c|c|c|}
\hline Com- & $\mathrm{vNH}$ & $v(N) C=C$ & $\gamma \mathrm{C}_{\mathrm{Ar}} \mathrm{H}$ & $\gamma \mathrm{C}_{\mathrm{Ar}} \mathrm{H}$ & $\mathrm{H}-3$ & $\mathrm{H}-4$ & $\mathrm{H}-5$ & $\mathrm{H}-6$ & $\mathrm{H}-7$ & $\mathrm{H}-2^{\prime}, 6^{\prime}$ & $\mathrm{H}-3^{\prime}, 5^{\prime}$ & $\mathrm{NH}$ & $\mathrm{NH}$ \\
\hline pound & band & band & band $^{d}$ & band ${ }^{\mathrm{e}}$ & $s^{d}$ & $\sim d^{d}$ & $\sim t^{d}$ & $\sim t^{d}$ & $\sim d^{d}$ & $d(2 \mathrm{H})^{\mathrm{e}}$ & $d / t(2 \mathrm{H})^{\mathrm{e}}$ & amide & indole \\
\hline $9 a$ & 3358 & 1641 & $\begin{array}{l}739 \\
733\end{array}$ & 844,820 & 7.83 & 7.70 & 7.11 & 7.31 & 7.51 & 7.48 & 7.73 & $11.6,12.0$ & 12.6 \\
\hline $9 b$ & 3346, 3294 & 1658 & 740 & 8.46 & 7.82 & 7.70 & 7.11 & 7.31 & 7.51 & 7.93 & 8.01 & $11.6,12.0$ & 12.8 \\
\hline $9 c$ & $\begin{array}{l}3390 \\
3216\end{array}$ & 1649 & 746 & 705 & 7.81 & 7.70 & 711 & 7.31 & 7.51 & 7.13 & - & $11.5,12.0$ & 12.6 \\
\hline 10 & 3221 & 1616 & 740 & 828 & - & 7.67 & 7.15 & 7.40 & 7.53 & $\sim 7.6$ & 7.44 & 11.1 & 12.4 \\
\hline 11 & $\sim 3450$ & 1649 & 754 & 716 & - & 7.68 & 7.18 & 7.42 & 7.56 & $\sim 7.7$ & 7.99 & $\sim 11.1$ & 12.3 \\
\hline 12 & 3260 & 1648 & 749 & 810 & 7.74 & 7.70 & 7.10 & 7.28 & 7.51 & $7.17^{f}$ & - & 12.9 & 12.0 \\
\hline 15 & 3230 & 1631 & 743 & 828 & - & 7.75 & 7.18 & 7.46 & 7.58 & 7.87 & 7.71 & - & 12.7 \\
\hline
\end{tabular}

aln $\mathrm{KBr}$ discs ( $\left.\mathrm{cm}^{-1}\right)$. Further bands, Ester: vC=O: 1713 (9b), 1735 (11); vC-O: 1276, 1153 (9b), 1307, 1191 (11), vC-O (methoxy groups): 1222, 1125 (9c), 1278, 1110 (12); ' In DMSO-d solution at $500 \mathrm{MHz}$. Chemical shifts in ppm $\left(\delta_{\mathrm{TMS}}=0 \mathrm{ppm}\right)$. Further signals: $\mathrm{CH}_{3}$ and $\mathrm{CH}_{2}(\mathrm{OEt}, 9 \mathrm{~b}, 11): 1.34, t, \mathrm{~J}: 7.1 \mathrm{~Hz}$ and 4.34 qa; $\mathrm{OCH}_{3}, \mathrm{~s}: 3.69$ (9c, $6 \mathrm{H}$, Pos 3', 5'), 3.80 (9c, 3H, Pos. 4'), 3.80, 3.90, 4.03 (12, 3-3H, Pos. 7', 6' and 5'); 'Assignments were supported by $\mathrm{HMQC}$ and ${ }^{1} \mathrm{H},{ }^{13} \mathrm{C}$ HMBC measurements; ${ }^{d}$ Indole ring; ${ }^{e}$ Aryl group; ${ }^{f}$ Pos. $4{ }^{\prime}$. 
Table 2. ${ }^{13} \mathrm{C}$ NMR chemical shifts ${ }^{\mathrm{a}}$ of compounds $\mathbf{9 a}-\mathrm{c}, \mathbf{1 0}-\mathbf{1 2}$ and $15^{\mathrm{b}}$

\begin{tabular}{|c|c|c|c|c|c|c|c|c|c|c|c|c|c|c|}
\hline Com- & $C=S$ & $C=0$ & $C-2$ & $C-3$ & $c-3 a$ & C -4 & $C-5$ & $C-6$ & C-7 & $C-7 a$ & $C-1^{\prime}$ & $C-2^{\prime}, 6^{\prime}$ & $C-3^{\prime}, 5^{\prime}$ & $C-4^{\prime}$ \\
\hline pound & ester & amide & \multicolumn{8}{|c|}{ indole ring } & \multicolumn{4}{|c|}{ aryl group } \\
\hline $9 a$ & 179.7 & 161.9 & 128.8 & 109.2 & 127.3 & 123.0 & 120.9 & 125.8 & 113.1 & 138.4 & 130.8 & 129.0 & 126.8 & 137.5 \\
\hline $9 b$ & 179.7 & 162.3 & $129.2^{\mathrm{e}}$ & 109.7 & 127.7. & 123.4 & 121.3 & 126.3 & 113.5 & 138.8 & 143.2 & 124.5 & 130.6 & 128.0 \\
\hline $9 c$ & 179.5 & 162.4 & 129.3 & 109.6 & 127.7 & 123.4 & 121.3 & 126.2 & 113.5 & 138.8 & 134.6 & 103.05 & 153.5 & 136.5 \\
\hline 10 & $?$ & $162.2^{c}$ & 123.8 & 110.9 & 121.9 & 120.8 & 121.4 & 127.5 & 114.1 & 138.4 & 128.9 & 123.7 & 129.9 & 123.8 \\
\hline 11 & $?$ & $?$ & 123.9 & 111.0 & 122.0 & 120.7 & $121.4^{d}$ & 127.5 & 114.2 & 138.6 & 126.2 & $121.5^{d}$ & 131.2 & $121.5^{d}$ \\
\hline 12 & $158.9^{e}$ & 160.6 & 129.9 & 107.4 & 127.8 & 123.2 & 121.2 & 125.6 & 113.4 & 138.4 & $147.2^{f}$ & $100.2^{\mathrm{g}}$ & $145.9^{h}$ & $154.4^{i}$ \\
\hline 15 & $175.4^{e}$ & 160.4 & 121.5 & 115.3 & 123.2 & 121.3 & 121.9 & 128.4 & 114.3 & 138.4 & 123.5 & 139.3 & 131.4 & 137.9 \\
\hline
\end{tabular}

aln ppm $\left(\delta_{\text {TMS }}=0 \mathrm{ppm}\right)$ at $125.7 \mathrm{MHz}$. Solvent: DMSO-d 6 . Further signals, $\mathrm{CH}_{3}: 15.1(9 \mathrm{~b}, 11), \mathrm{CH}_{2}: 61.6(9 \mathrm{~b})$, 61.3 (11), 21.8 (11); $\mathrm{OCH}_{3}$ (Pos. 3,5 and 4): 56.9 and 61.0 (9c), $\mathrm{OCH}_{3}$ (Pos. 5-7): 57.1, 61.3, 61.8(12); C=O (ester): 166.0 (9b), 166.2 (11). Due to slow motion of the NH-C=NAr $\rightleftarrows \mathrm{N}=\mathrm{C}-\mathrm{NHAr}$ moiety (tautomerism) were not possible to identify the $\mathrm{SC}=(\mathbf{1 0}$ and $\mathbf{1 1})$ and $\mathrm{C}=\mathrm{O}$ (amide) lines(11); ${ }^{\mathrm{b}}$ Assignments were supported by DEPT (except for 9a, 11), 2D-HMQC, ${ }^{1} \mathrm{H},{ }^{13} \mathrm{C} \mathrm{HMBC}$, for 12 also by ${ }^{1} \mathrm{H},{ }^{15} \mathrm{~N} \mathrm{HMBC}$ measurements; 'Broadened signal; ${ }^{d}$ Reversed assignments is also possible; ${ }^{e} \mathrm{SC}=\mathrm{N}$ line; ${ }^{\mathrm{f} / \mathrm{g} / \mathrm{h} / \mathrm{i}} \mathrm{C}-3 \mathrm{a}, 4,5$ and 6 lines, resp. in benzthiazole moiety.

Concerning the ring-chain tautomerism possible in 10-12, the difference in the shape and shift of NH signal between 10-11 and 12, respectively, is striking. In 12 the preferred structure of the aromatic benzothiazole part excludes the tautomerism and the amide NH signal is sharp and has higher shift at 12.0 ppm. In contrast, the tautomeric equilibrium of $\mathbf{1 0}$ and 11 results in a broad NH signal and a lower shift (11.1 ppm).

Table 3. In vitro antiproliferative effects of compounds prepared

\begin{tabular}{|c|c|c|c|c|c|}
\hline \multirow{2}{*}{ Compound } & \multirow{2}{*}{ Concentr. } & \multicolumn{4}{|c|}{ Growth inhibition, $\% \pm$ SEM $^{a}$} \\
\hline & & HeLa & A2780 & MCF7 & A431 \\
\hline \multirow[t]{2}{*}{$9 a$} & $10 \mu \mathrm{M}$ & - & - & - & n.t. \\
\hline & $30 \mu \mathrm{M}$ & $47.5 \pm 1.7$ & - & $49.2 \pm 0.7$ & n.t. \\
\hline \multirow[t]{2}{*}{$9 b$} & $10 \mu \mathrm{M}$ & $61.4 \pm 0.5$ & $-^{a}$ & - & $45.2 \pm 0.2$ \\
\hline & $30 \mu \mathrm{M}$ & $58.8 \pm 1.4$ & - & - & $50.2 \pm 0.3$ \\
\hline \multirow[t]{2}{*}{ 9c } & $10 \mu \mathrm{M}$ & $35.5 \pm 1.8$ & $29.6 \pm 1.0$ & - & - \\
\hline & $30 \mu \mathrm{M}$ & $48.2 \pm 2.9$ & $52.0 \pm 1.4$ & $31.2 \pm 1.9$ & $44.8 \pm 0.8$ \\
\hline \multirow[t]{2}{*}{10} & $10 \mu \mathrm{M}$ & - & $61.5 \pm 1.0$ & $44.8 \pm 1.4$ & - \\
\hline & $30 \mu \mathrm{M}$ & $63.8 \pm 0.7$ & $79.1 \pm 0.5$ & $70.1 \pm 0.8$ & $70.6 \pm 0.7$ \\
\hline \multirow[t]{2}{*}{11} & $10 \mu \mathrm{M}$ & $61.2 \pm 0.9$ & $55.3 \pm 1.5$ & $36.0 \pm 2.1$ & $67.2 \pm 0.8$ \\
\hline & $30 \mu \mathrm{M}$ & $81.7 \pm 2.4$ & $87.6 \pm 1.8$ & $82.3 \pm 2.5$ & $81.7 \pm 0.6$ \\
\hline \multirow[t]{2}{*}{12} & $10 \mu \mathrm{M}$ & - & $60.4 \pm 1.2$ & $43.3 \pm 1.8$ & - \\
\hline & $30 \mu \mathrm{M}$ & $89.0 \pm 0.9$ & $94.7 \pm 0.1$ & $92.5 \pm 0.2$ & $68.4 \pm 1.1$ \\
\hline \multirow[t]{2}{*}{15} & $10 \mu \mathrm{M}$ & $47.1 \pm 1.9$ & $89.6 \pm 2.1$ & $69.6 \pm 1.3$ & n.t. \\
\hline & $30 \mu \mathrm{M}$ & $93.0 \pm 2.3$ & $95.3 \pm 0.4$ & $89.8 \pm 0.3$ & n.t. \\
\hline \multirow[t]{2}{*}{ Cisplatin } & $10 \mu \mathrm{M}$ & $42.6 \pm 2.3$ & $83.6 \pm 1.2$ & $53.0 \pm 2.3$ & $88.5 \pm 0.5$ \\
\hline & $30 \mu \mathrm{M}$ & $99.9 \pm 0.3$ & $95.0 \pm 0.3$ & $86.9 \pm 1.2$ & $90.2 \pm 1.8$ \\
\hline
\end{tabular}

a Substances eliciting less than $25 \%$ inhibition of cell proliferation were regarded as ineffective and the results are not presented; n.t.: not tested 
The in vitro antiproliferative activities of the compounds prepared were examined on human tumor cell lines $^{40}$ HeLa (cervix adenocarcinoma), MCF7 (breast adenocarcinoma), A2780 (ovarian carcinoma) and A431 (squamous carcinoma) by means of MTT assay. The results are summarized in Table 3.

Modest growth inhibition effects were observed for isocyclobrassinin analogs 9a-c. The ring-closed 4arylimino-thiazines $\mathbf{1 0}$ and $\mathbf{1 1}$ performed moderate cell growth inhibition (up to $67.2 \%, 10 \mu \mathrm{M}$, compound 11, A431 cell line). Interestingly, thiazole 12 also has relatively good inhibition effect on cell line A2780 (60.4\% at $10 \mu \mathrm{M}$ ). Of our compounds prepared 2-(4-chlorophenylthio)-4,5-dihydro-1,3-thiazino[5,6-b]indole-4-one 15 showed the highest antiproliferative activity exhibiting $89.6 \%(10 \mu \mathrm{M})$ growth inhibition on cell line A2780. This value is comparable to that of cisplatin.

\section{Conclusions}

In summary, isomeric analogs of cyclobrassinin phytoalexin possessing the 1,3-thiazino[5,6-b]indole-4-one skeleton have been prepared, and were found to have noteworthy in vitro antiproliferative effects. The 2-(4chlorophenylthio)-4,5-dihydro-1,3-thiazino[5,6-b]indole-4-one derivative 15, a sulfur analogue of $\beta$-carboline showed the highest antiproliferative activity. The structures of the novel compounds prepared were confirmed by means of IR and NMR spectroscopy and discussed in some detail.

\section{Experimental Section}

General. Melting points were determined on a Kofler micro melting apparatus and are uncorrected. Elemental analyses were performed with a Perkin-Elmer 2400 CHNS elemental analyser. Merck Kieselgel 60F 254 plates were used for TLC, and Merck Silica gel 60 (0.063-0.100) for column chromatography. The ${ }^{1} \mathrm{H}$ and ${ }^{13} \mathrm{C} N M R$ spectra were recorded in $\mathrm{CDCl}_{3}$ solution in $5 \mathrm{~mm}$ tubes at room temperature, on a Bruker DRX 500 spectrometer at $500\left({ }^{1} \mathrm{H}\right)$ and $126\left({ }^{13} \mathrm{C}\right) \mathrm{MHz}$, with the deuterium signal of the solvent as the lock and TMS as internal standard. DEPT spectra were run in a standard manner, using only the $\Theta=135^{0}$ pulse to separate $\mathrm{CH} / \mathrm{CH}_{3}$ and $\mathrm{CH}_{2}$ lines phased "up" and "down", respectively. The 2D-HSQC and -HMBC spectra were obtained by using the standard Bruker pulse programs. Indole-2-carboxylic acid was purchased from Fluka. Indole-2carbonyl chloride was prepared by an earlier method. ${ }^{35}$

The antiproliferative properties of the prepared analogs were determined in vitro against a panel of human adherent cancer cell lines ${ }^{40}$ including HeLa (cervix adenocarcinoma), MCF7 (breast adenocarcinoma), A2780 (ovarian carcinoma) and A431 (squamous carcinoma). All cell lines were purchased from the European Collection of Cell Cultures (ECCAC, Salisbury, UK). The cells were maintained in minimal essential medium (Lonza Ltd, Basel, Switzerland) supplemented with $10 \%$ foetal bovine serum, $1 \%$ non-essential amino acids and an antibiotic-antimycotic mixture. Near-confluent cancer cells were seeded onto a 96-well microplate at the density of 5000 cells/well and, after overnight standing, new medium $(200 \mu \mathrm{L})$ containing the tested compound at 10 and $30 \mu \mathrm{M}$ was added. After incubation for $72 \mathrm{~h}$ at $37 \stackrel{\circ}{\circ}$ in humidified air containing $5 \% \mathrm{CO}_{2}$, the viability of the cells was determined by the addition of $5 \mathrm{mg} / \mathrm{mL} 3-(4,5-$ dimethylthiazol-2-yl)-2,5diphenyltetrazolium bromide (MTT) solution. During a 4-h contact period, the MTT was converted by intact mitochondrial reductase and the precipitated formazan crystals were dissolved in $100 \mu \mathrm{L}$ DMSO. Finally, the reduced MTT was assayed at $545 \mathrm{~nm}$, using a microplate reader; wells with untreated cells were utilized as controls. All in vitro experiments were carried out on two microplates with at least five parallel wells. Stock 
solutions of the tested substances $(10 \mathrm{mM})$ were prepared in DMSO. The highest DMSO content of the medium (0.3\%) did not have any substantial effect on the cell proliferation. Cisplatin (Ebewe Pharma GmbH, Unterach, Austria) was used as the reference agent.

General procedure for the preparation of $\mathbf{N}$-aryl- $\boldsymbol{N}^{\prime}-(\mathbf{1 H}$-indole-2-carbonyl)thioureas (9a-c). To a stirred solution of potassium thiocyanate $(2.0 \mathrm{~g}, 20.6 \mathrm{mmol})$ in dry acetone $(30 \mathrm{~mL})$ a solution of freshly prepared indole-2-carbonyl chloride $(3.4 \mathrm{~g}, 20,0 \mathrm{mmol})$ in acetone $(10 \mathrm{ml})$ was added in one portion at room temperature. The reaction mixture was stirred for $1 \mathrm{~h}$ at room temperature and filtered through a sintered glass. After the evaporation of the solvent, the crystalline product was taken up in diethyl ether $(2 \times 10 \mathrm{~mL})$ and filtered. Isothiocyanate (7) was used in the next step without any further purification.

To the stirred solution of $1 \mathrm{H}$-indole-2-carbonyl isothiocyanate 7 (0.5 g, 2,4 mmol) in acetone $(10 \mathrm{~mL})$ the appropriately substituted aniline $\mathbf{8 a}-\mathbf{c}$ derivative was added portionwise. The reaction mixture was stirred at room temperature for $1 \mathrm{~h}$ (9c precipitated as white crystalline product) and then concentrated. The crystalline residues were triturated with acetone $(9 a-c)$, filtered off and purified as indicated.

$\mathbf{N}$-(4-chlorophenyl)- $\boldsymbol{N}^{\prime}$-(1H-indole-2-carbonyl)thiourea (9a). A pale-yellow crystalline powder, mp $209-212$ oC (methanol) , yield 92\%. Anal. Calcd. for $\mathrm{C}_{16} \mathrm{H}_{12} \mathrm{ClN}_{3} \mathrm{OS}$ (329.80): C, 58.27; $\mathrm{H}, 3.67 ; \mathrm{N}, 12.74 ; \mathrm{S}, 9.72$. Found: C, 58.05; H, 3.89; N, 12.55; S, 9.95.

$\mathbf{N}$-[4-(ethoxycarbonyl)phenyl]-N'-(1H-indole-2-carbonyl)thiourea (9b). A pale-yellow crystalline powder, $\mathrm{mp}$ 212-215 으 (methanol), yield 87\%. Anal. Calcd. for $\mathrm{C}_{19} \mathrm{H}_{17} \mathrm{~N}_{3} \mathrm{O}_{3} \mathrm{~S}$ (367.42): $\mathrm{C}, 62.11 ; \mathrm{H}, 4.66 ; \mathrm{N}, 11.44 ; \mathrm{S}, 8.73$. Found: $\mathrm{C}, 62.40 ; \mathrm{H}, 4.81 ; \mathrm{N}, 11.27 ; \mathrm{S}, 8.95$.

$\mathbf{N}^{\prime}$-(1H-indole-2-carbonyl)-N-(3,4,5-trimethoxyphenyl)thiourea (9c). A pale-yellow crystalline powder, $\mathrm{mp}$ 208-210 ㅇ (methanol+chloroform), yield 93\%. Anal. Calcd. for $\mathrm{C}_{19} \mathrm{H}_{19} \mathrm{~N}_{3} \mathrm{O}_{4} \mathrm{~S}$ (385.44): C, 59.21; $\mathrm{H}, 4.97 ; \mathrm{N}$, 10.90; S, 8.32. Found: C, 59.07; H, 5.21; N, 10.67; S, 8.61.

General procedure for the preparation of 4,5-dihydro-1,3-thiazino[5,6-b]indole-4-one derivatives $(10,11)$ and benzothiazole (12). To an intensively stirred suspension of thiourea derivatives $9 a-c(0.7 \mathrm{mmol})$ in dichloromethane $(20 \mathrm{~mL})$, phenyltrimethylammonium tribromide $(0.26 \mathrm{~g}, 0.69 \mathrm{mmol})$ was added in one portion at room temperature. After stirring for $5 \mathrm{~min}$, triethylamine $(0.39 \mathrm{~mL}, 2.8 \mathrm{mmol})$ was added in one portion to the clear solution. The solvent was evaporated (water bath $<50{ }^{\circ} \mathrm{C}$ ) and the residue was purified by column chromatography, using $n$-hexane/ethyl acetate 3:2 as an eluent, to give 10-12 as crystalline powders.

2-(4-Chlorophenylimino)-4,5-dihydro-1,3-thiazino[5,6-b]indole-4-one (10). A yellow crystalline powder, mp 302-305 ㅇ, yield 78\%. Anal. Calcd. for $\mathrm{C}_{16} \mathrm{H}_{10} \mathrm{CIN} \mathrm{Cl}_{3} \mathrm{OS}$ (327.79): C, 58.63; $\mathrm{H}, 3.08 ; \mathrm{N}, 12.82 ; \mathrm{S}, 9.78$. Found: C, 58.38; H, 3.27; N, 12.57; S, 10.05.

2-[(4-(Ethoxycarbonyl)phenylimino]-4,5-dihydro-1,3-thiazino[5,6-b]indole-4-one (11). A yellow crystalline powder, mp 289-291 으, yield 81\%. Anal. Calcd. for $\mathrm{C}_{19} \mathrm{H}_{15} \mathrm{~N}_{3} \mathrm{O}_{3} \mathrm{~S}$ (365.41): C, 62.45; H, 4.14; N, 11.50; S, 8.78. Found: $\mathrm{C}, 62.28 ; \mathrm{H}, 4.40 ; \mathrm{N}, 11.33 ; \mathrm{S}, 9.05$.

2-(Indole-2-carbonylamino)-5,6,7-trimethoxy-benzothiazole (12). A pale-yellow crystalline powder, $\mathrm{mp} 258-$ $261 \stackrel{\circ}{\circ}$, yield 84\%. Anal. Calcd. for $\mathrm{C}_{19} \mathrm{H}_{17} \mathrm{~N}_{3} \mathrm{O}_{4} \mathrm{~S}$ (383.42): C, 59.52; $\mathrm{H}, 4.47 ; \mathrm{N}, 10.96 ; \mathrm{S}, 8.36$. Found: $\mathrm{C}, 59.77 ; \mathrm{H}$, $4.67 ;$ N, $10.75 ;$ S, 8.24 .

General procedure for the preparation of 2-(4-chlorophenylthio)-4,5-dihydro-1,3-thiazino[5,6-b]indole-4-one (15). To a stirred solution of acyl isothiocyanate $7(0.5 \mathrm{~g}, 2,4 \mathrm{mmol})$ in acetone $(10 \mathrm{~mL})$ thiophenol 13 derivative was added portionwise. The reaction mixture was stirred at room temperature for $1 \mathrm{~h}$ and then concentrated. 
The crystalline residue was triturated with diisopropylether+ethyl acetate. Product $\mathbf{1 4}$ was filtered off and used without further purification in the next ring-closing step.

To an intensively stirred suspension of thiourea derivative $14(0.7 \mathrm{mmol})$ in dichloromethane $(20 \mathrm{~mL})$, phenyltrimethylammonium tribromide $(0.26 \mathrm{~g}, 0.69 \mathrm{mmol})$ was added in one portion at room temperature. After stirring for $5 \mathrm{~min}$, triethylamine $(0.39 \mathrm{~mL}, 2.8 \mathrm{mmol})$ was added in one portion to the clear solution. The solvent was evaporated (water bath $<50{ }^{\circ} \mathrm{C}$ ) and the residue was purified by column chromatography, using $n$ hexane/ethyl acetate 3:2 as an eluent, to give 15 as a yellow crystalline powder, $\mathrm{mp} 288-290$ 으, yield $67 \%$. Anal. Calcd. for $\mathrm{C}_{16} \mathrm{H}_{9} \mathrm{ClN}_{2} \mathrm{OS}_{2}$ (344.84): C, 55.73; $\mathrm{H}, 2.63 ; \mathrm{N}, 8.12 ; \mathrm{S}, 18.60$. Found: $\mathrm{C}, 55.93 ; \mathrm{H}, 2.82 ; \mathrm{N}, 8.33 ; \mathrm{S}$, 18.76

\section{References}

1. Takasugi, M.; Monde, K.; Katsui, N.; Shirata, A. Bull. Chem. Soc. Jpn. 1988, 61, 285.

https://doi.org/10.1246/bcsj.61.285

2. Jeandet, P. Molecules 2015, 20, 2770. (Special Issue; Phytoalexins: Current Progress and Future Prospects)

https://doi.org/10.3390/molecules20022770

3. Mehta, R. G.; Liu, J.; Constantinou, A.; Thomas, C. F.; Hawthorne, M.; You, M.; Gerhüser, C.; Pezzuto, J. M.; Moon, R. C.; Moriarty, R.M Carcinogenesis 1995, 16, 399.

4. Budovská, M.; Kudličková, Z.; Kutschy, P.; Pilátová, M.; Mojžiš, J. Tetrahedron Lett. 2015, 56, 3945. https://doi.org/10.1016/j.tetlet.2015.05.001

5. Csomós, P.; Zupkó, I.; Réthy, B.; Fodor, L.; Falkay, G.; Bernáth, G. Bioorg. Med. Chem. Lett. 2006, 16, 6273.

https://doi.org/10.1016/j.bmcl.2006.09.016

6. Banerjee, T.; DuHadaway, J. B.; Gaspari, P.; Sutanto-Ward, E.; Munn, D. H.; Mellor, A. L.; Malachowski, W. P.; Prendergast, G. C.; Muller, A.J. Oncogene 2008, 27, 2851.

https://doi.org/10.1038/sj.onc.1210939

7. Izutani, Y.; Yogosawa, S.; Sowa, Y.; Sakai, T. Int. J. Oncol. 2012, 40, 816.

8. Kello, M.; Drutovic, D.; Chripkova, M.; Pilátová, M.; Budovska, M.; Kulikova, L.; Urdzik, P.; Mojžiš, J. Molecules 2014, 19, 10877.

https://doi.org/10.3390/molecules190810877

9. Lee, J. H.; Kim, C.; Sethi, G.; Ahn K. S. Oncotarget 2015, 6, 6386.

https://doi.org/10.18632/oncotarget.3443

10. Romeo, G.; Russo, F.; Guccione, S.; Chabin, R.; Kuo, D.; Knight, W. B. Bioorg. Med. Chem. Lett. 1994, 4, 2399.

https://doi.org/10.1016/S0960-894X(01)80398-X

11. Kutschy, P.; Suchý, M.; Andreani, A.; Dzurilla, M.; Kováčik, V.; Alföldi, J.; Rossi, M.; Gramatová, M. Tetrahedron 2002, 58, 9029.

https://doi.org/10.1016/S0040-4020(02)01124-9

12. Kulkarni, P. M.; Kulkarni, A. R.; Korde, A.; Tichkule, R. B.; Laprairie, R. B.; Denovan-Wright, E. M.; Zhou, H.; Janero, D. R.; Zvonok, N.; Makriyannis, A.; Cascio, M. G.; Pertwee, R. G.; Thakur, G. A. J. Med. Chem. 2016, 59, 44.

https://doi.org/10.1021/acs.jmedchem.5b01303 
13. Dienel, G. A.; Ball, K. K.; Cruz, N. F. J. Neurochem. 2007, 102, 466.

https://doi.org/10.1111/j.1471-4159.2007.04595.x

14. Hong, F.; Zaidi, J.; Cusack, B.; Richelson, E. Bioorg. Med. Chem. 2002, 10, 3849. https://doi.org/10.1016/S0968-0896(02)00342-5

15. La Regina G.; Silvestri, R.; Gatti, V.; Lavecchia, A.; Novellino, E.; Befani; O.; Turini, P.; Agostinelli, E. Bioorg. Med. Chem. 2008, 16, 9729.

https://doi.org/10.1016/i.bmc.2008.09.072

16. Hayashi, S.; Ohashi, K.; Nakata, E.; Emoto, C. Eur. J. Med. Chem. 2012, 55, 228.

https://doi.org/10.1016/i.ejmech.2012.07.021

17. Borza, I.; Kolok, S.; Gere, A.; Ágai-Csongor, É.; Ágai, B.; Tárkányi, G.; Horváth, C.; Barta-Szalai, G.; Bozó, É.; Kiss, C.; Bielik, A.; Nagy, J.; Farkas, S.; Domány, G. Bioorg. Med. Chem. Lett. 2003, 13, 3859.

https://doi.org/10.1016/S0960-894X(03)00708-X

18. Boateng, C. A.; Bakare, O. M.; Zhan, J.; Banala, A. K.; Burzynski, C.; Pommier, E.; Keck, T. M.; Donthamsetti, P.; Javitch, J. A.; Rais, R.; Slusher, B. S.; Xi, Z.-X.; Newman, A. H. J. Med. Chem., 2015, 58, 6195.

https://doi.org/10.1021/acs.jmedchem.5b00776

19. Ölgen, S.; Çoban, T. Arch. Pharm. 2002, 335, 331. https://doi.org/10.1002/1521-4184(200209)335:7<331::AID-ARDP331>3.0.CO;2-7

20. Nazaré, M.; Matter, H.; Will, D. W.; Wagner, M.; Urmann, M.; Czech, J.; Schreuder, H.; Bauer, A.; Ritter, K.; Wehner, V. Angew. Chem. Int. Ed. 2012, 51, 905.

https://doi.org/10.1002/anie.201107091

21. Javed, T.; Shattat, G. F. J. Heterocyclic Chem. 2005, 42, 217.

https://doi.org/10.1002/jhet.5570420206

22. Minehira, D.; Takeda, D.; Urata, H.; Kato, A.; Adachi, I.; Wang, X.; Matsuya, Y.; Sugimoto, K.; Takemura, M.; Endo, S.; Matsunaga, T.; Hara, A.; Koseki, J.; Narukawa, K.; Hirono, S.; Toyooka, N. Bioorg. Med. Chem. 2012, 20, 356.

https://doi.org/10.1016/i.bmc.2011.10.073

23. Bhattacharya, S. K.; Aspnes, G. E.; Bagley, S. W.; Boehm, M.; Brosius, A. D.; Buckbinder, L.; Chang, J. S.; Dibrino, J.; Eng, H.; Frederick, K. S.; Griffith, D. A.; Griffor, M. C.; Guimarães, C. R. W; Guzman-Perez, A.; Han, S.; Kalgutkar, A. S.; Klug-McLeod, J.; Garcia-Irizarry, C.; Li, J.; Lippa, B.; Price, D. A.; Southers, J. A.; Walker, D. P.; Wei, L.; Xiao, J.; Zawistoski, M. P.; Zhao, X. Bioorg. Med. Chem. Lett. 2012, 22, 7523.

https://doi.org/10.1016/j.bmcl.2012.10.039

24. Laufer, S.; Lehmann, F. Bioorg. Med. Chem. Lett. 2009, 19, 1461.

https://doi.org/10.1016/j.bmcl.2009.01.023

25. Pala, N.; Stevaert, A.; Dallocchio, R.; Dessì, A.; Rogolino, D.; Carcelli, M.; Sanna, V.; Sechi, M.; Naesens, L. ACS Med. Chem. Lett., 2015, 6, 866.

https://doi.org/10.1021/acsmedchemlett.5b00109

26. Sessions, E. H.; Chowdhury, S.; Yin, Y.; Pocas, J. R.; Grant, W.; Schröter, T.; Lin, L.; Ruiz, C.; Cameron, M. D.; LoGrasso, P.; Bannister, T. D.; Feng, Y. Bioorg. Med. Chem. Lett. 2011, 21, 7113.

https://doi.org/10.1016/j.bmcl.2011.09.084

27. Ueda, S.; Kato, M.; Inuki, S.; Ohno, H.; Evans, B.; Wang, Z.; Peiper, S. C.; Izumi, K.; Kodama, E.; Matsuoka, M.; Nagasawa, H.; Oishi, S.; Fujii, N. Bioorg. Med. Chem. Lett. 2008, 18, 4124.

https://doi.org/10.1016/j.bmcl.2008.05.092

28. Honda, T.; Nagahara, H.; Mogi, H.; Ban, M.; Aono, H. Bioorg. Med. Chem. Lett. 2011, $21,1782$. 
https://doi.org/10.1016/j.bmcl.2011.01.063

29. Cananzi, S.; Merlini, L.; Artali, R.; Beretta, G. L.; Zaffaroni, N.; Dallavalle, S. Bioorg. Med. Chem. 2011, 19, 4971.

https://doi.org/10.1016/j.bmc.2011.06.056

30. Watanabe, K.; Kakefuda, A.; Yasuda, M.; Enjo, K.; Kikuchi, A.; Furutani, T.; Naritomi, Y.; Otsuka, Y.; Okada, M.; Ohta, M. Bioorg. Med. Chem, 2013, 21, 5261.

https://doi.org/10.1016/i.bmc.2013.06.025

31. De Martino, G.; La Regina, G.; Coluccia, A.; Edler, M. C.; Barbera, M. C.; Brancale, A.; Wilcox, E.; Hamel, E.; Artico, M.; Silvestri, R. J. Med. Chem. 2004, 47, 6120.

https://doi.org/10.1021/jm049360d

32. Zhang, H.-Z.; Drewe, J.; Tseng, B.; Kasibhatla, S.; Cai, S. X. Bioorg. Med. Chem. 2004, 12, 3649.

https://doi.org/10.1016/j.bmc.2004.04.017

33. Wirth, T.; Schmuck, K.; Tietze, L. F.; Sieber, S. A. Angew. Chem. Int. Ed. 2012, 51, 2874.

https://doi.org/10.1002/anie.201106334

34. Csomós, P.; Fodor, L.; Sohár, P.; Bernáth, G. Tetrahedron 2005, 61, 9257.

https://doi.org/10.1016/j.tet.2005.07.068

35. Csomós, P.; Fodor, L.; Mándity, I.; Bernáth, G. Tetrahedron 2006, 63, 4983.

https://doi.org/10.1016/j.tet.2007.03.132

36. Csomós, P.; Fodor, L.; Bernáth, G.; Csámpai, A.; Sohár, P. J. Heterocyclic Chem. 2011, 48, 1079. https://doi.org/10.1002/jhet.607

37. Fodor, L.; Csomós, P.; Fülöp, F.; Csámpai, A.; Sohár, P. Tetrahedron 2013, 69, 410. https://doi.org/10.1016/j.tet.2012.09.102

38. Holly, S.; Sohár, P. In Theoretical and Technical Introduction to the Series Absorption Spectra in the Infrared Region; Láng, L.; Prichard, W. H. Eds.; Akadémiai Kiadó: Budapest, 1975; p. 75, p. 84.

39. Sohár, P. In Nuclear Magnetic Resonance Spectroscopy; CRC Press: Boca Raton, Florida, 1983; Vol. 1, p. 185.

40. Mosmann, T. J. Immunol. Methods 1983, 65, 55.

https://doi.org/10.1016/0022-1759(83)90303-4 